\title{
PEMBIBITAN DURIAN KUNYIT SEBAGAI USAHA PRODUKINTELEKTUAL KAMPUS
}

\author{
I.A.L. Dewi ${ }^{1}$, N.M. Pradnyawathi ${ }^{2}$, I.K. Sardiana ${ }^{3}$ dan N.N. Darmiati ${ }^{4}$
}

\begin{abstract}
ABSTRAK
Program pengembangan usaha produk intelektual kampus bertujuan untuk: (1) komersialisasi Ipteks kreativitas kampus sebagai sumber pembiayaan untuk pengebangan institusi; (2) memacu jiwa kewirausahaan dikalangan insan kampus, dan (3) membantu masyarakat mendapatkan bibit varietas Durian Kunyit. Metode pelaksanaan meliputi aspek bisnis perusahaan yang terdiri dari: penyediaan bahan baku, produksi, proses produksi, manajemen, pemasaran, sumberdaya manusia, fasilitas, dan financial. Bahan baku terdiri sumber batang bawah dari durian lokal, dan entris dari pucuk tanaman durian kunyit Produk yang dihasilkan berupa bibit Durian kunyit unggul dengan produktivitas di atas 60-70 biji /pohon, kapasitas produksi tahun 2018 yaitu sebanyak 2000 pohon. Proses produksi dimulai dari penyemaian batang bawah, penyambungan (grafting) batang bawah dengan batang atas, dan pemeliharaan. Manajemen usaha terdiri dari unit produksi dan pengembangan Ipteks, administrasi serta pemasaran. Pemasaran dilakukan secara langsung, kemitraan dengan Pemda dan konsiniasi dengan kios/toko pertanian. Sumberdaya manusia yang terlibat terdiri dari : 1 orang ketua, tiga kepala bidang, satu tenaga administrasi, dan 2 orang tenaga kerja operasional. Fasilitas yang tersedia berupa lahan kebun bibit seluas $1000 \mathrm{~m} 2$, ruang kantor dan nursery $100 \mathrm{~m} 2$.
\end{abstract}

Kata kunci : pembibitan, usaha, produk, intelektual kampus, durian kunyit.

\begin{abstract}
The campus intellectual product business development program aims to: (1) commercialize campus creativity science and technology as a source of funding for institutional development; (2) spur the entrepreneurial spirit among campus personnel, and (3) help the community get the seeds of Durian Turmeric varieties. The implementation method includes business aspects which consist of: supply of raw materials, production, production processes, management, marketing, human resources, facilities, and financial. The raw material consists of rootstock from local durian, and entris from the top of the turmeric durian plant. The product is in the form of superior Turmeric Durian seeds with productivity above 60-70 seeds / tree, the production capacity in 2018 is 2000 trees. The production process begins with seeding the rootstock, grafting the lower stem with the upper stem, and maintenance. Business management consists of production and technology development and production units, administration and marketing. Marketing is done directly, partnerships with local governments and consultations with agricultural stores. The human resources involved consisted of: 1 chairman, three heads of fields, one administrative staff, and 2 operational workers. The available facilities are $1000 \mathrm{~m} 2$ of nursery land, $100 \mathrm{~m} 2$ of office space and nursery.
\end{abstract}

Keywords: nursery, business, product, campus intellectual, durian kunyit.

\footnotetext{
${ }^{1}$ PS Agribisnis Fakultas Pertanian Universitas Udayana, listiadewi60@unud.ac.id

${ }^{2}$ PS Agroekoteknologi Fakultas Pertanian Universitas Udayana, pradnyawathi@unud.ac.id

${ }^{3}$ PS Agroekoteknologi Fakultas Pertanian Universitas udayana, ksardiana@unud.ac.id

${ }^{4}$ PS Agroekoteknologi Fakultas Pertanian Universitas udayana, darmiati@unud.ac.id
} 


\section{PENDAHULUAN}

Durian Kunyit adalah salah satu varietas durian lokal yang sangat digemari oleh penikmat durian di Bali, bahkan oleh wisatawan yang datang ke Bali. Tanaman ini endemik tumbuh di kawasan Kecamatan Pupuan Kabupaten Tabanan dan tidak dijumpai di wilayah lainnya di Bali. Nama Durian Kunyit merupakan sebutan yang diberikan oleh masyarakat karena warna daging buahnya yang kuning bening seperti warna rimpang kunyit. Karakteristik buah "Durian Kunyit" adalah sebagai berikut : buah yang berbentuk bulat telur dengan warna hijau kekuningan. Duri kulitnya berbentuk kerucut kecil dan rapat. Buahnya berukuran sebesar kelapa gading dengan penampilan sangat menarik dengan bobot buah $1-2 \frac{1}{2} \mathrm{~kg}$. Daging buah agak tebal, berlemak, bertekstur agak lembek, berserat halus, beraroma sedang atau tidak begitu tajam. Keunggulan "Durian Kunyit " dibandingkan dengan varietas durian yang umum di Bali seperti : durian Bestala, durian montong, durian kane dan lain-lain, yaitu rasanya yang khas tidak terlalu manis, gurih, lembut, dan baunya yang tidak menyengat. Oleh sebab itu, durian kunyit menjadi buah-buahan paporit dan diburu oleh pedagang dan penikmat durian baik masyarakat lokal, maupun manca negara yang berwisata ke wilayah Pupuan.

Persoalan yang dijumpai di lapangan adalah semakin terbatasnya populasi tanaman Durian Kunyit. Hasil inventariasasi yang dilakukan oleh tim peneliti Fakultas Pertanian Universitas Udayana pada tahun 2013-2014 melalui Hibah MP3EI dan Hibah Daerah menunjukkan bahwa di seluruh Kecamatan Pupuan populasi durian kunyit hanya mencapai 50 pohon. Bahkan pohon yang masih produktif, tidak lebih dari 15 pohon yang terdapat di Desa Belimbing. Kelangkaan tanaman durian tersebut terjadi karena tanaman durian kunyit umumnya tumbuh sendiri, bukan hasil budidaya atau penanaman. Usaha penanaman sudah banyak dilakukan oleh masyarakat melalui perbanyakan melalui biji buah (generatif), tetapi hasil yang dieroleh kurang memuaskan karena tanaman baru yang dihasilkan tidak sama dengan karakteristik induknya. Selain itu, waktu produksi yang terlalu lama yaitu mencapai 10 tahun juga menjadi penyebab peningkatan populasi tanaman tersebut. Karena banyak pohon durian kunyit yang sudah tua dan tidak produktif lagi, maka populasinya semakin menyusut. Oleh sebab itu, untuk menjaga populasi durian kunyit dan pelestarian plasma nuftah unggul tersebut maka sangat diperlukan usaha pembibitan dengan aplikasi teknologi yang mampu menghasilkan tanaman hasil perbanyakan yang sama dengan induknya.

Memperhatikan uraian tersebut di atas mendorong munculnya ide untuk melakukan pembibitan/perbanyakan tanaman tersebut sebagai unit usaha produk intelektual kampus. Tujuan dari pengabdian ini adalah melakukan pembibitan Durian Kunyit sebagai usaha komersial. Menurut Sardiana (2010), usaha produk intelektual kampus merupakan upaya untuk komersialisasi hasil pengembangan Iptek di perguruan Tinggi. Unit tersebut selanjutnya diharapkan dapat menjadi sumber income generating bagi kampus. Selain itu, unit usaha produk intelektual kampus juga dapat menjadi wadah pengembangan kewirausahaan dikalangan mahasiswa menuju terbentuknya mahasiswa wirausaha (Sardiana, dkk., 2015).

\section{METODE PELAKSANAAN}

Proses produksi bibit Durian Kunyitdimulai dari penyemaian entris bawah, koleksi entris atas, penyambungan entris bawah dan entris atas, pemeliharaan bibit melalui pemupukan dan penanggulangan hama dan penyakit, serta panen. Pada tahapan produksi bibit, ini dilakukan langkah-langkah sebagai berikut: 


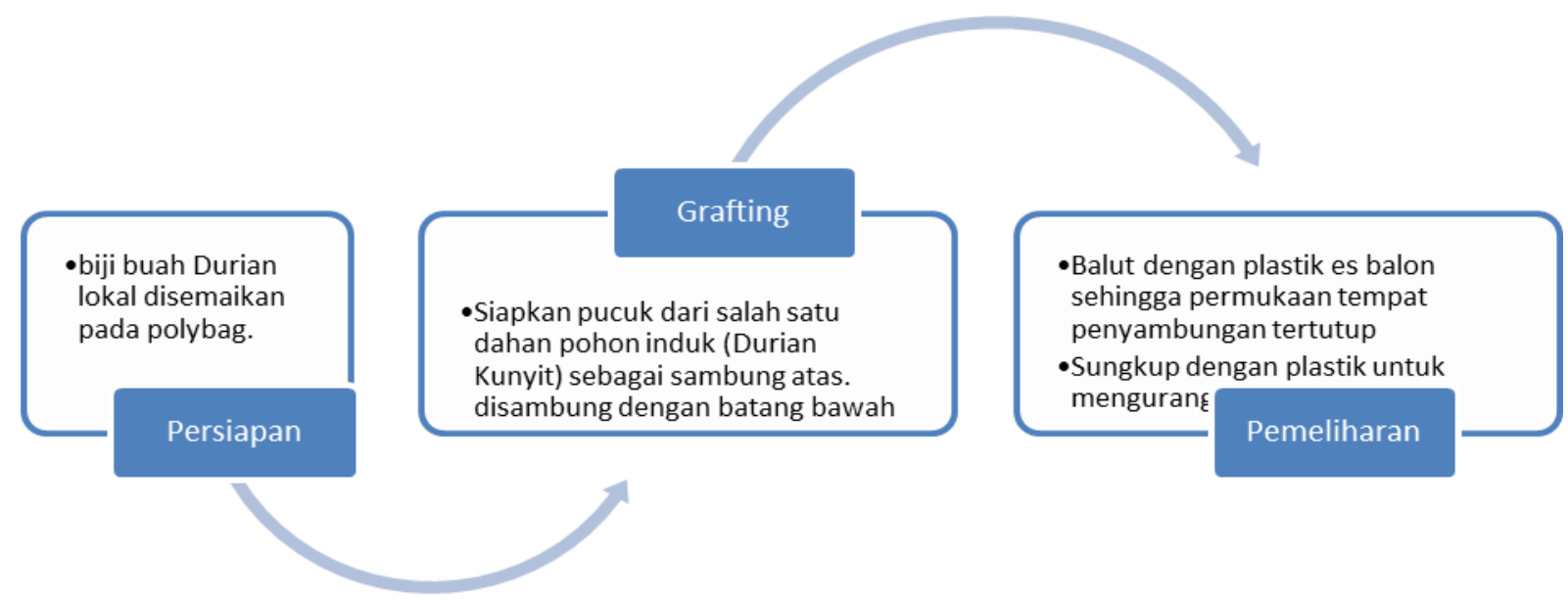

Setelah selesai letakan di tempat teduh (rumah paranet), tidak terkena matahari langsung dan tidak terkena hujan, selanjutnya disiram setiap sore. Setelah berumur 3 minggu, plastik pembungkus/sungkup dilepaskan. Sambung pucuk/drafting berhasil ditandai dengan batang masih hijau, tidak busuk dan tidak bewarna coklat/hitam. Setelah berhasil rawat bibit tersebut, setiap 2 minggu siram dengan larutan (air + ZPT organik + Trichoderma). Setelah 3 bulan bibit sudah siap ditanam (dijual).

\section{HASIL DAN PEMBAHASAN}

Kegiatan pengadaan batang atas atau pohon induk yang dilakukan dalam kegiatan PPUPIK dilakukan dengan melakukan survei ke petani di Desa Belimbing yang memiliki tanaman Durian Kunyit. Pohon Durian Kunyit yang di pergunakan untuk batang atas adalah bagian pucuk tanaman. Untuk dapat memperoleh pucuk tanaman maka dilakukan investasi pohon Durian Kunyit yang dimiliki petani sekitar. Dari kegiatan survei tersebut diperoleh lima pohon Durian Kunyit, yang disewa untuk diambil pucuknya.

Target produksi bibit pada tahun 2018 sebanyak 2000 pohon. Proses produksi melibatkan sebanyak 4 tenaga kerja terdiri dari 1 manajer produksi, 1 tenaga memanjat untuk koleksi entris, dan 2 orang tenaga grafting. Produksi diawali dengan pemupukan terhadap pohon durian yang akan dijadikan pohon induk sumber entris dengan jenis pupuk NPK. Setelah dua bulan pada tanaman induk akan tumbuh pucuk baru, setelah tiga bulan pucuk tersebut siap dipotong/dipanen untuk dijadikan entris.

Produk yang dihasilkan unit PPUPIK adalah bibit Durian Kunyit. Bibit Durian Kunyit diperoleh melalui beberapa tahap yaitu sebagai berikut.

a. Pengadaan Batang Bawah

Pengadaan batang bawah yang dilakukan dalam kegiatan PPUPIK adalah dimulai dari penyemaian biji durian. Biji durian yang dipergunakan dalam pengadaan batang bawah adalah biji Durian Lokal yang ditanam masyarakat sekitar. Pemilihan biji yang akan dipergunakan sebagai batang bawah adalah biji dari buah yang matang sempurna, secara morfologi biji yang dipergunakan adalah biji yang berwarna coklat, segar, bernas, utuh, tidak cacat dan luka. Setiap gelombang penyemaian biji durian lokal dilakukan sebanyak 500 biji. Setelah biji durian berkecambah sekitar umur 6-8 minggu setelah semai, kemudian dilakukan pemilihan tanaman yang cocok untuk batang bawah. Memilih tanaman yang akan dipergunakan sebagai batang bawah tanaman induk yang memiliki ciri pertumbuhan batang bawah tegak dan kokoh, tinggi $15-25 \mathrm{~cm}$ 
dan mulai membentuk daun yang masih tertutup, kondisi fisik sehat secara visual, vigor, normal (tidak kontet/roset/sukulen), dan diameter cukup besar sebanding dengan entres yang digunakan.

b. Grafting

Grafting merupakan suatu teknik penyambungan batang bawah dengan batang atas dari tanaman berbeda namun jenisnya sama sehungga tercapai persenyawaan. Kombinasi kedua tanaman tersubut akan terus tumbuh menjadi tanaman baru. Teknik ini mulai banyak dipergukana untuk dipergunakan karena dengan teknik grafting ini lebih cepat menghasilkan bibit. Dua bulan dari waktu semai, bibit durian sudah bisa disambung pucuk.

Proses grafting yang telah dilakukan sebanyak tiga (3) kali sesuai dengan gelombang penyemaian biji. Setelah penyambungan batang yang disambung ditutup plastik, untuk menjaga kelembaban tanaman dan serangan hama penyakit. Setelah proses grafting tanaman selesai tanaman dipindahkan ke nursery yang telah disediakan.

c. Pemeliharaan

Proses pemeliharaan dilakukan setelah dilakukan proses grafting. Proses pemeliharaan terdiri dari beberapa kegiatan yaitu penyiraman, pemupukan, dan penggulmaan. Selain ketiga kegiatan tersebut dilakukan juga pengecekan keberhasilan proses grafting. Untuk mengetahui tingkat keberhasilan teknik grafting dilakukan pemeriksaan terhadap bidang sambungan pada umur 15 hari setelah penyambungan. Bila bidang sambungan berwarna hijau segar dan tampak tumbuh tunas baru, pertanda penyambungan berhasil. Sebaliknya bila bidang sambungan berwarna coklat atau kering, berarti mini grafting tersebut gagal. Setelah sambungan berumur $1-1,5$ bulan, isolasi pembalut bidang sambungan bisa dilepaskan. Pemeliharaan secara intensif sambungan terutama penyiraman, pengendalian OPT pada masa-masa pertumbuhan $2-3$ bulan setelah pelepasan ikatan. Setelah ikatan sambungan dilepas, bibit sudah siap untuk dipasarkan.

d. Penjajagan pemasaran/promosi ke instansi pengguna

Pemasaran dilakukan melalui sosialisasi dan promosi ke calon konsumen yaitu kepada Pemda Tabanan. Promosi dan penjajagan kerjasama dilakukan secara terbatas karena kapasitas produksi masih sedikit, karena keterbatasan bibit batang bawah dan ketersediaan bagian atas. Selain itu terdapat penyusutan jumlah produksi tanaman akibat adanya kegagalan proses grafting, dimana kegagalan ini umumnya mencapai $20 \%$ dari total tanaman yang di grafting.

\section{KESIMPULAN DAN SARAN}

Kesimpulan yang dapat diambil dari pelaksanaan kegiatan PPUPIK Pembibitan Durian Kunyit 2018 adalah sebagai berikut:

Pelaksanaan kegiatan terbagi menjadi tiga tahap yaitu sebagai berikut.

a. Penyiapan sarana dan fasilitas PPUPIK terdiri dari kegiatan inventarisasi, pengadaaan batang atas (pohon induk), membangun nursery, penanaman bibit Durian Kunyit untuk kebun induk.

b. Proses produksi Bibit Durian Kunyit terdiri dari pengadaan batang bawah, grafting, dan pemeliharaan. Penjajagan pemasaran/promosi ke instansi pengguna dalam hal ini adalah Pemda Tabanan.

\section{UCAPAN TERIMA KASIH}

Penulis mengucapkan terimakasih kepada Direktorat Jendral Riset dan Pengabdian Masyarakat atas dana yang diberikan sehingga kegiatan pengabdian masyarakat Pembibitan Durian Kunyit sebagai Usaha Produk Intelektual Kampus dapat terlaksana.

\section{DAFTAR PUSTAKA}

Balai Statistik Propinsi Bali. 2012. Bali dalam Angka 2012. Balai Statistik Propinsi Bali Renon. Denpasar. 
Prastowo N, J.M. Roshetko. 2006.Tehnik Pembibitan dan Perbanyakan Vegetatif Tanaman Buah. World Agroforestry Centre (ICRAF) dan Winrock International. Bogor, Indonesia. p.100

Kantor Deputi Menegristek Bidang Pendayagunaan dan Pemasyarakatan Ilmu Pengetahuan dan Teknologi. 2000. Tentang Budidaya Pertanian Durian (Bombaceaesp).

Sardiana, I.K., B.R.T. Putri, I.G. Suranjaya, N.L.R. Purnawan. 2015. Pengembangan Kewirausahaan Di Universitas Udayana. Majalah Aplikasi Ipteks Ngayah : Vol. 6, No. 1, hal. 91-101.

Sardiana, I.K. 2010. Unit pembibitan Tanaman Ritual (upakara). Majalah Aplikasi Ipteks Ngayah. Vol 1. No. 1. Hal. 13-21. 